\title{
PENGARUH SPREAD TINGKAT SUKU BUNGA, NON PERFORMING LOAN, DAN BOPO TERHADAP PROFITABILITAS
}

\section{Ida I Dewa Ayu Ekadini Badung1 I Putu Yadnya ${ }^{2}$}

\author{
${ }^{1,2}$ Fakultas Ekonomi dan Bisnis Universitas Udayana, Bali, Indonesia \\ e-mail: ekadini30@gmail.com
}

\begin{abstract}
ABSTRAK
Penelitian ini bertujuan untuk mengetahui pengaruh Spread Tingkat Suku Bunga, NPL dan BOPO terhadap Profitabilitas BPR di Kota Denpasar periode 2014-2016. Penelitian ini menggunakan metode observasi non partisipan dengan sampel yang digunakan sebanyak 19 BPR di Kota Denpasar. Teknik analisis data yang digunakan analisis regresi linier berganda. Hasil analisis penelitian ini menunjukkan bahwa secara parsial Spread berpengaruh positif tidak signifikan terhadap Return On Asset (ROA) pada BPR di Kota Denpasar 2014-2016. Non Performing Loan (NPL) berpengaruh negatif signifikan terhadapROA pada BPR di Kota Denpasar 2014-2016. Biaya Operasional Terhadap Pendapatan Operasional (BOPO) berpengaruh negatif signifikan terhadapROA pada BPR di Kota Denpasar 2014-2016. Implikasi dari penelitian ini semakin tinggi rasio Spread maka akanmeningkatkan ROA perusahaan perbankan. Sedangkan NPL dan BOPO semakin tinggi rasio variabel tersebut, maka ROA perusahaan perbankan akan mengalami penurunan, sehingga untuk meningkatkan ROAperusahaan perbankan harus menekanNPLdanmemanfaatkan sumber dan sistem yang ada.
\end{abstract}

Kata Kunci:spread tingkat suku bunga, NPL, BOPO, profitabilitas

\begin{abstract}
The purpose of this study is to determine the effect of Spread Rate of Interest Rate, NPL and BOPO on Profitability of Rural Banks in Denpasar period 2014-2016. This research uses non participant observation method with the sample used as many as 19 BPR in Denpasar City. Data analysis technique used multiple linear regression analysis. The results of this study show that partially positive Spread has no significant effect on Return On Assets (ROA) on BPR in Denpasar City 2014-2016. Non Performing Loan (NPL) has a significant negative effect on ROA in BPR in Denpasar City 2014-2016. Operational Costs to Operating Income (BOPO) have a significant negative effect on ROA in BPR in Denpasar City 2014-2016. The implications of this study the higher Spread ratio will increase the ROA of banking companies. While the NPL and BOPO the higher the ratio of these variables, then the ROA of banking companies will decrease, so to improve the ROA of banking companies have to press NPL and utilize existing sources and systems.
\end{abstract}

Keywords: Interest Rate Spread, NPL, BOPO, Profitability. 


\section{PENDAHULUAN}

Bank adalah suatu lembaga yang berfungsi sebagai perantara keuangan antara pihak yang memiliki kelebihan dana dengan pihak yang kekurangan dana. Perbankan juga berperan sebagai lembaga penyelenggara dan penyedia layanan jasa-jasa dibidang keuangan serta lalu lintas sistem pembayaran (Agent of services). Berdasarkan fungsinya perbankan dibedakan menjadi dua jenis antara lain bank umum dan bank perkreditan rakyat (BPR). Menurut undang-undang (UU) perbankan nomor 7 tahun 1992 sebagaimana telah diubah dengan UU Nomor 10 tahun 1998, bahwa berdasarkan jenis kegiatan usahanya, bank dapat dibagi menjadi dua yaitu Bank Umum dan BPR. BPR merupakan komponen yang berperan penting dalam memajukan usaha mikro, kecil dan menengah (UMKM). BPR sebagai lembaga keuangan yang menyediakan jasa simpan pinjam dana khusunya bagi masyarakat di daerah pedesaan maupun masyarakat golongan menengah yang berada didaerah perkotaan. Perkreditan merupakan kegiatan penting bagi BPR dikarenakan kredit merupakan sumber pendapatan bank. Saat menyalurkan kredit bank akan memperoleh pendapatan yang berasal dari bunga kredit setelah dikurangi biaya dan pengeluaran bank.

Hal ini menjadi keunggulan dari BPR dibandingkan bank umum, karena BPR memberikan pelayanan perbankkan kepada masyarakat yang sulit memiliki akses ke bank umum. Perbankkan nasional yang tangguh, termasuk industri BPR yang sehat, kuat, efisien, dan memiliki daya saing, ini diperlukan dalam menciptakan stabilitas sistem keuangan, mendorong pertumbuhan ekonomi nasional dan mendukung perkembangan usaha yang bersifat dinamis. BPR 
Ida I DewaAyu Ekadini Badung, Pengaruh Spread....

mempunyai prinsip kerja yaitu mengandalkan kecepatan dan kemudahan namun tetap berpengangan teguh pada prinsip kehati-hatian (prudential banking). Pemeliharaan sumber-sumber modal yang memadai dapat meningkatkan kepercayaan deposan, kreditur, dan pasar pendanaan, sehingga mendukung kesehatan dan kestabilan bank. BPR diteliti karena memiliki keunggulan yakni dari sisi faktor kedekatan dan penyebaran BPR sampai ke pelosok desa dan lebih memahami karakter setiap nasabahnya yang tersebar.

Berdasarkan hasil pengamatan ROA yang terjadi pada BPR Kota Denpasar dari tahun 2014-2016, terjadi fluktuasi selama tiga tahun peiode tersebut dapat dilihat pada tahun 2014-2016. ROA terendah terletak pada tahun 2016 sebesar 0,17\% dan ROAtertinggi dicapai pada tahun 2015 yaitu sebesar 12,34\%. BPR Kota Denpasar menunjukkan bahwa sedang mengalami kesulitan untuk menjaga stabilitas pertumbuhan ROA setiap tahunnya. Fenomena ini yang mendorong peneliti untuk mengangkat BPR Kota Denpasar sebagai lokasi penelitian.

Salah satu tujuan bank adalah memperoleh profitabilitas yang maksimal untuk mengoptimalkan kegiatan operasionalnya. Profitabilitas merupakan kemampuan perusahaan dalam memperoleh laba atau ukuran efektivitas pengelolaan manajemen perusahaan agar perusahaan mengetahui berapa laba yang diperoleh dalam suatu periode tertentu (Wiagustini, 2014:86). Dalam mencapai profitabilitasnya, dimana semua bank akan menghadapi berbagai risiko. Risiko yang mungkin terjadi akan menimbulkan kerugian bagi bank jika tidak dideteksi serta tidak dikelola dengan baik sebagaimana mestinya (Idroes, 2011:22). Kondisi ini mengakibatkan semua pihak yang berada dalam lingkup 
perbankkan menjadi terdorong untuk mengukur seberapa tingginya risiko yang mungkin akan timbul dan nantinya bank dapat mengantisipasinya dan mampu meminimalkan risiko yang terjadi agar memperoleh profitabilitas yang diharapkan.

Bank perlu menjaga profitabilitas agar tetap stabil atau bahkan meningkat. Return on Asset (ROA) adalah rasio pofitabiltas yang sangat penting bagi bank, karena rasio ini digunakan untuk mengukur seberapa tinggi efektivitas dari bank itu sendiri dalam memperoleh keuntungan dengan memanfaatkan aktiva yang dimiliki oleh bank (Wiagustini, 2014:81). ROA merupakan rasio profitabilitas yang menunjukkan perbandingan antara laba setelah pajak dengan total asset bank. (Riyadi, 2006:156). Semakin tinggi tingkat ROA yang dimiliki, maka semakin efisien penggunaan aktiva yang mengakibatkan laba yang diperoleh bank akan semakin maningkat (Kurnia dan Wisnu, 2012).

Salah satu strategi bank untuk mendapatkan nasabah agar bersedia menabung di bank yaitu dengan memberikan bunga. Dalam dunia perbankan, suku bunga dapat dikatakan sebagai harga yang harus dikeluarkan oleh bank kepada nasabah yang menyimpan dana (yang memiliki simpanan). Bunga merupakan suatu ukuran yang digunakan debitur untuk membayar kreditur. Pada dasarnya suku bunga adalah harga atas pinjaman yang dinyatakan dalam persentase. Suku bunga bisa dikatakan merupakan balas jasa penggunaan modal yang dibayar pada waktu tertentu berdasarkan kesepakatan. Berdasarkan kegiatan bank dalam menghimpun dan menyalurkan dana dari masyarakat maka suku bunga dapat dikelompokkan dalam dua jenis, yaitu: Bunga simpanan merupakan 
Ida I DewaAyu Ekadini Badung, Pengaruh Spread....

bunga yang diberikan sebagai rangsangan atas balas jasa bagi nasabah yang menyimpan uangnya di bank yang merupakan harga yang harus dibayar bank kepada nasabahnya dan bunga pinjaman merupakan biaya atau harga yang harus dibayar oleh nasabah (peminjam) kepada bank atas dana yang diberikan kepadanya.

Manajemen risiko diperlukan untuk mendukung pencapaian dari tujuan perusahaan, dan mengingatkan pihak-pihak yang ada didalamnya bahwa risiko dapat terjadi pada setiap kegiatan dan tingkatan dalam setiap organisasi sehingga setiap anggota harus mengambil dan mengelola risiko tersebut sesuai dengan wewenang dan tanggungjawabnya masing-masing (Idroes, 2011:6). Hanafi (2013:1) menyatakan, risiko kegagalan muncul karena adanya kodisi ketidakpastian yang akan dapat menimbulkan kerugian, apabila semakin tinggi ketidakpastian yang dihadapi maka semakin tinggi pula risiko yang akan terjadi. Jadi, dalam hal mengelola risiko maka diperlukan adanya manajemen risiko yang optimal.

Peraturan Bank Indonesia No.1/25/PBI/2009 tentang penerapan manajemen risiko bagi bank umum mengidentifikasikan risiko yang dihadapi oleh bank memiliki delapan tipe risiko yaitu risiko kredit, risiko pasar, risiko likuiditas, risiko operasional, risiko hukum, risiko reputasi, risiko stratejik, dan risiko kepatuhan. Berdasarkan delapan risiko tersebut, yang seringkali dihadapi oleh sektor perbankan adalah risiko kredit, risiko likuiditas, risiko operasional, karena risiko tersebut dapat memicu terjadinya kerugian yang sangat besar bagi sektor perbankan. 
Risiko kredit merupakan risiko kerugian yang berhubungan dengan pihak peminjam (counterparty) dimana pihak peminjam tidak mau atau tidak dapat memenuhi kewajibannya untuk membayar kembali dana yang dipinjam secara penuh pada saat sudah jatuh tempo atau sesudahnya, (Idroes, 2011:23). Salah satu rasio keuangan yang dapat digunakan untuk mengukur risiko kredit ialah Non Performing Loan (NPL). Siamat (2005:358) NPL, merupakan dimana pinjaman yang sedang mengalami kesulitan atau macet dalam pelunasannya akibat dari adanya faktor kesengajaan atau faktor luar (eksternal) yang merupakan diluar kendali debitur. NPL adalah perbandingan dari kredit bermasalah dengan total kredit yang dinyatakan dalam persentase. Riyadi (2006:161) menyatakan, apabila semakin besar tingkat NPL maka menunjukan bahwa bank tersebut tidak profesional dalam mengelola kreditnya, dan ini memberikan indikasi bahwa tingkat risiko atas pemberian kredit pada bank tersebut cukup tinggi dengan tingginya NPL yang dihadapi bank tersebut. Jika NPL naik maka artinya terjadi kenaikan kredit bermasalah yang akan dapat menurunkan laba perusahaan, sehingga terjadi hubungan negatif antara NPL dengan profitabilitas.

Risiko operasional merupakan risiko kerugian atau ketidakcukupan dari proses internal, sistem yang gagal, sumber daya manusia, dan faktor eksternal (Idroes, 2011:23). Risiko operasional akan mucul karena adanya penurunan laba yang dipengaruhi oleh biaya operasional bank. Apabila biaya yang dikeluarkan bank lebih besar dari pendapatan yang diperoleh, maka akan mengakibatkan penurunan kinerja keuangan bank tersebut. Dalam mencegah terjadinya hal ini, maka bank perlu mengukur seberapa tinggi tingkat risiko operasional yang 
mungkin akan dihadapi dngan menggunakan rasio keuangan Biaya Operasional terhadap Pendapatan Operasional (BOPO). Riyadi (2006:159), BOPO merupakan rasio perbandingan antara biaya operasional dengan pendapatan operasional, dimana semakin rendah tingkat BOPO maka akan semakin baik pula kinerja manejemen bank tersebut, karena bank akan lebih efisien dalam memanfaatkan sumber daya yang ada.

Berdasarkan penelitian yang dilakukan oleh Oktavia (2009) dan Kalengkongan (2013) menyatakan suku bunga berpengaruh positif signifikan terhadap ROA. Penelitian yang dilakukan Irfan (2015) dan Sahara (2013) suku bunga berpengaruh negatif dan signifikan terhadap ROA. Sedangkan hasil penelitian yang dilakukan oleh Aditya dkk (2016), Wibowo (2013) dan Ashar (2015) suku bunga berpengaruh positif tidak signifikan terhadap profitabilitas.

Berdasarkan penelitian yang dilakukan oleh Devy M et al. (2015) dan Raj Bhattarai (2016) menemukan hasil yang sama bahwa NPL berpengaruh negatif dan signifikan terhadap ROA. Sedangkan menurut penelitian Buchory (2015) dan Mohammad (2013) menemukan NPL berpengaruh positif namun tidak berpengaruh signifikan terhadap ROA. Berbeda dengan Ndoka Sokol (2016), Haryanto (2016) dan Suryanto (2017) bahwa NPL berpengaruh signifikan terhadap ROA. Kolapo et al. (2012) menemukan hasil NPL memiliki pengaruh negatif terhadap ROA. Begitu pula penelitian oleh Ngandlan dan Riadi (2010), Han dan JI-yong (2012), Joseph et al. (2012), dan Nusantara (2009) menemukan hasil yang sama dengan Devy M et al. (2015) dan Raj Bhattarai (2016) yaitu dimana NPL memiliki pengaruh negatif dan signifikan terhadap ROA. 
Penelitian mengenai pengaruh BOPO terhadap ROA dilakukan oleh Syafri (2012) menemukan hasil bahwa BOPO memiliki pengaruh negatif terhadap ROA. Penelitian yang dilakukan oleh Defri (2012) dan Nusantara (2009) menemukan hasil bahwa BOPO memiliki pengaruh negatif dan signifikan terhadap ROA, sedangkan hasil penelitian yang dilakukan Buchory (2015) menemukan hasil berpengaruh positif dan signifikan terhadap ROA. Kuncoro dan Suharjono (2011) mendapatkan hasil bahwa BOPO berpengaruh positif dan signifikan terhadap ROA.

Manajemen keuangan sebagai salah satu fungsi yang dapat mempengaruhi kehidupan bank, dan membahas mengenai pengelolaan keuangan yang pada dasarnya dapat dilakukan baik oleh individu, perusahaan, maupun pemerintah. Martono dan Agus Harjito (2008:4) manajemen keuangan adalah segala aktivitas perusahaan yang berhubungan dengan bagaimana memperoleh dana, menggunakan dana, dan mengelola asset sesuai tujuan perusahaan secara menyeluruh. Menurut Kasmir (2014:8) tentang pengertian Bank menurut UndangUndang Nomor 10 tahun 1998 tentang perubahan atas UU No. 7 tahun 1992 tentang Perbankan pada Bab 1 dan Pasal 1 serta ayat 2 dijelaskan bahwa, bank adalah badan usaha yang menghimpun dana dari masyarakat dalam bentuk simpanan dan menyalurkannya kepada masyarakat dalam bentuk kredit dan atau bentuk-bentuuk lainnya dalam rangka meningkatkan taraf hidup rakyat banyak. Sedangkan perbankan adalah segala sesuatu yang menyangkut tentang bank, mencakup kelembagaan, kegiatan usaha, serta cara dan proses dalam melaksanakan kegiatan usahanya. 
Laporan keuangan akan melaporkan posisi perusahaan pada satu titik waktu tertentu maupun operasinya selama suatu periode di masa lalu. Berdasarkan sudut pandang manajemen, analisis laporan keuangan akan bermanfaat untuk membantu mengantisipasi kondisi-kondisi di masa depan dan sebagai titik awal untuk melakukan perencanaan langkah-langkah yang akan meningkatkan kinerja perusahaan di masa mendatang. Rasio-rasio keuangan dirancang untuk membantu mengevaluasi laporan keuangan.

Suatu perusahaan setiap saat atau secara berkala perlu melakukan analisis terhadap kinerjanya, demikian pula dengan bank. Analisis terhadap kinerja perusahaan dilakukan untuk kepentingan manajemen, pemilik atau pemerintah sebagai upaya untuk mengetahui kondisi usaha saat ini dan sekaligus memudahkan dalam menentukan kebijakan bisnis di masa mendatang. Rivai (2013) menyatakan dalam mengukur kinerja suatu bank, selain mengacu kepada ketentuan mengenai Tingkat Kesehatan Bank, banyak bank yang melengkapi analisis kinerja keuangannya dengan menggunakan rasio-rasio keuangan bank.

Bank Perkreditan Rakyat atau biasa disebut dengan BPR, merupakan lembaga keuangan resmi yang sudah diatur berdasarkan UU No.10 Tahun 1998 yang dijelaskan bahwa BPR adalah bank yang melaksanakan kegiatan usaha secara konvensional atau berdasarkan prinsip syariah yang ada dalam kegiatannya tidak memberikan jasa dalam lalu lintas pembayaran. Kegiatan operasional BPR memiliki jangkauan yang terbatas, maka BPR bisa dikatakan tidak dapat memberikan jasa dalam lalu lintas pembayaran. Hal ini berbeda dengan bank 
umum, dimana bank umum dalam menjalankan kegiatannya dapat memberikan jasa dalam setiap lalu lintas pembayaran.

Perbedaan yang mendasari antara bank umum dengan BPR adalah terletak pada kegiatan operasionalnya masing-masing. Kegiatan operasional yang dilakukan bank umum yaitu cakupannya lebih luas dibandingkan dengan BPR. Yang artinya, produk yang ditawarkan oleh bank umum pilihannya lebih beragam jika dibandingkan dengan BPR, karena hal ini disebabkan kebebasan yang dimiliki bank umum untuk menentukan produk dan jasa, sedangkan BPR memiliki keterbatasan tertentu sehingga dalam kegiatannya lebih sempit (Kasmir, 2014:16).

Spread tingkat suku bunga bank adalah pendapatan utama bagi bank yang akan menentukan besarnya pendapatan bersih bank. Besarnya spread adalah margin (selisih) antara tingkat bunga pinjaman (cost of funds) dan tingkat bunga simpanan (lending rate). Semakin tinggi spread atau net margin yang mampu diciptakan oleh bank, maka hal ini mengindikasikan tingkat keuntungan bank meningkat sehingga laba yang didapatkan bank akan semakin meningkat. (Kasmir, 2012) menyatakan bahwa salah satu strategi bank untuk dapat menghimpun dana dari masyarakat dalam jumlah banyak dengan memberikan balas jasa berupa bunga simpanan. Bagi bank yang berprinsip konvensional dapat berupa bunga, sedangkan untuk bank yang berprinsip syariah berupa bagi hasil. Kenaikan suku bunga kredit menyebabkan biaya bunga pinjaman ikut meningkat, sehingga pendapatan yang diterima bank dari bunga pinjaman kredit akan ikut 
meningkat. Jika pendapatan bunga bank naik maka akan meningkatkan laba atau keuntungan bank yang bersangkutan.

Rasio keuangan yang dapat digunakan untuk mengukur risiko keuangan adalah Non Performing Loan (NPL). (Puspitasari, 2009) NPL merupakan kemampuan manajemen bank dalam pengelolaan kredit macet yang diberikan oleh bank. Berdasakan Surat Edaran Bank Indonesia No.13/24/DPNP/2011, NPL bertujuan untuk mengetahui jumlah nominal kredit dengan kualitas kurang lancar, diragukan, dan macet. NPL merupakan cerminan dari resiko kredit, dimana semakin rendah tingkat NPL maka akan semakin rendah pula resiko kredit yang ditanggung oleh pihak bank. NPL dianggap sebagai ketentuan mekanisme kendali atas kerugian pinjaman yang diharapkan oleh perusahaan, Haneef et al. (2012).

Riyadi (2006:241) besarnya NPL yang diperbolehkan oleh Bank Indonesia adalah maksimal 5\%, dan jika besarnya NPL melebihi angka tersebut maka akan mempengaruhi penilaian tingkat kesehatan bank yang bersangkutan, hal ini akan mengurangi nilai yang diperoleh oleh bank itu sendiri. Semakin besar tingkat NPL menunjukan bahwa bank tersebut tidak profesional dalam mengelola kredit, dan ini memberikan idikasi bahwa tingkat resiko kredit pada bank tersebut cukup tinggi sejalan dengan tingginya NPL yang dihadapi oleh bank.

Risiko operasional adalah ketidakpastian mengenai kegiatan usaha yang dilakukian oleh suatu lembaga keuangan. Idroes (2011:23), risiko operasional didefinisikan sebagai resiko kerugian atau keditakcukupan dari proses internal, sumber daya manusia, dan sistem yang gagal atau dari peristiwa eksternal. Risiko operasional biasanya terjadi akibat adanya penurunan pada keuntungan 
yangdipengaruhi oleh biaya operasional bank. Dimana bank dalam menjalankan usaha tentunya memerlukan biaya dalam mendukung operasionalnya. Apabila biaya yang dikeluarkan lebih besar dari pendapatan yang diperoleh bank, maka akan mengakibatkan penurunan kinerja keuangan bank tersebut. Untuk mengantisipasi hal itu, bank perlu mengukur seberapa besar risiko operasional yang mungkin terjadi dengan menggunakan rasio keuangan, yaitu rasio Biaya Operasional terhadap Pendapatan Operasional (BOPO).

Profitabilitas merupakan kemampuan suatu perusahaan untuk dalam mengelola asset dan modal yang dimiliki untuk memperoleh laba, (Sartono, 2010:122). Riyanto (2013:53) profitabilitas adalah kemampuan perusahaan mendapatkan laba melalui semua kemampuan dan sumber yang ada seperti penjualan, kas, modal, jumlah karyawan, jumlah cabang dan lain sebagainya.

Spread tingkat suku bunga bank adalah pendapatan utama bagi bank yang akan menentukan besarnya pendapatan bersih bank. Besarnya spread adalah margin (selisih) antara tingkat bunga pinjaman (cost of funds) dan tingkat bunga simpanan (lending rate), (Kasmir, 2014). Semakin tinggi spread atau net margin yang mampu diciptakan oleh bank, maka hal ini mengindikasikan tingkat keuntungan bank meningkat sehingga laba yang didapatkan bank akan semakin meningkat. Kenaikan suku bunga kredit menyebabkan biaya bunga pinjaman ikut meningkat, sehingga pendapatan yang diterima bank dari bunga pinjaman kredit akan ikut meningkat. Jika pendapatan bunga bank naik maka akan meningkatkan laba atau keuntungan bank yang bersangkutan. 
Penelitian sebelumnya mengenai variabel Spread Tingkat Suku Bunga Terhadap Profitabilitas yang dilakukan oleh Oktavia (2009) dan Kalengkongan (2013) mendapatkan hasil suku bunga berpengaruh positif signifikan terhadap ROA.H $\mathrm{H}_{1}$ : Spread Tingkat Suku Bunga berpengaruh positif signifikan terhadap profitabilitas pada BPR Kota Denpasar.

Rasio yang berkaitan dengan risiko kredit adalah NPL. NPL dapat diketahui dangan menghitung persentase antara kredit bermasalah dengan total kredit. Semakin rendah atau semakin kecil NPL, maka profitabilitas yang dihasilkan oleh bank tersebut akan semakin tinggi. Jika sebaliknya apabila NPL yang terdapat pada bank tersebut tinggi, maka bank akanmengalami kerugian yang disebabkan karena pendapatan bunga yang diperoleh dari pinjaman akan rendah, hal ini akan berdampak pada penurunan profitabilitas bank tersebut.

Penelitian sebelumnya mengenai variabel Non Performing Loan Terhadap Profitabilitas yang dilakukan oleh Devy M (2015) dan Raj Bhattarai (2016) mendapatkan hasil NPL berpengaruh negatif terhadap profitabilitas, yang didukung juga oleh Kolapo et al (2012), Ngandlan dan Riadi (2010), Han dan JIyong (2012), Joseph et al (2012) dan Nusantara (2009) menemukan hasil yang sama diman NPL berpengaruh negatif terhadap profitabilitas. $\mathrm{H}_{2}$ : NPL berpengaruh negatif signifikan terhadap profitabilitas pada BPR Kota Denpasar.

Biaya Opersional terhadap Pendapatan Opersional (BOPO) adalah rasio keuangan yang membandingkan antara biaya opersional dengan pendapatan opersional. Semakin kecil dan rendah tingkat BOPO, maka akan semakin efisien dan optimal kinerja manajemen bank tersebut karena bank telah memanfaatkan 
sumber daya dan sistem yang ada Riyadi (2006:159). Apabila terjadi peningkatan BOPO, maka akan mengakibatkan menurunnya kinerja bank yang diikuti pula dengan penurunan profitabilitas pada bank tersebut.

Penelitian sebelumnya mengenai variabel BOPO Terhadap Profitabilitas yang dilakukan oleh Syafri (2012) menemukan hasil bahwa BOPO berpengaruh negatif terhadap profitabilitas, begitu pula oleh Defri (2012), Nusantara (2009) menemukan hasil yang sama bahwa BOPO berpengaruh negatif terhadap profitabilitas. $\mathrm{H}_{3}$ : $\mathrm{BOPO}$ berpengaruh negatif signifikan terhadap profitabilitas pada BPR Kota Denpasar.

\section{METODOLOGI PENELITIAN}

Variabel terikat dalam penelitian ini adalah profitabilitas yang diukur dengan menggunakan ROA. Variabel bebas dalam penelitian ini adalah Spread Tingkat Suku Bunga, NPL, dan BOPO. Data kuantitatif, data yang dinyatakan dalam bentuk angka-angka, yaitu data-data keuangan BPR Kota Denpasar meliputi rasio keuangan serta laporan keuangan periode (2014-2016) yang meliputi neraca dan laporan laba rugi. Data keuangan meliputi data mengenai rasio Spread Tingkat Suku Bunga, NPL dan BOPO.

Data kualitatif, data yang tidak dapat dinyatakan dalam bentuk angka-angka atau satuan tertentu seperti penjelasan atas Peraturan Otoritas Jasa Keuangan (OJK) tentang Kewajiban Penyediaan Modal Minimum bagi BPR. Sumber data yang dipergunakan adalah sumber sekunder. Sumber data sekunder dalam penelitian ini antara lain rasio keuangan dan laporan keuangan BPR Kota Depasar periode (2014 -2016). Laporan keuangan BPR diperoleh dari laporan keuangan 
Ida I DewaAyu Ekadini Badung, Pengaruh Spread....

publikasi triwulanan BPR yang di-download melalui websiteOJK (www.ojk.go.id).

Populasi dalam penelitian ini adalah seluruh BPR pada Kota Denpasar yang berkantor pusat di wilayah kerja Provinsi Bali. Jumlah populasi dalam penelitian ini adalah 19 BPR di Kota Denpasar terbagi menjadi Denpasar Utara sebanyak 1 BPR, Denpasar Selatan sebanyak 6 BPR, Denpasar Barat sebanyak 6 BPR, dan Denpasar Timur sebanyak 6 BPR (sumber : www.ojk.go.id). Teknik pengambilan sampel yang digunakan adalah metode sensus, karena sampel yang diolah diambil dari semua anggota populasi.

Metode pengumpulan data yang digunakan dalam penelitian ini adalah metode observasi non participant, yaitu penelitian yang tidak terlibat secara langsung dan hanya sebagai pengamat independen (Sugiyono, 2014:204). Jenis data-data sekunder yang diperoleh secara langsung yaitu dengan melakukan download data keuangan BPR Kota Denpasar periode 2014-2016 melalui website OJK (www.ojk.go.id).

Penelitian ini menggunakan teknik analisis regresi linier berganda untuk pengolahan data, dimana teknik ini digunakan untuk mengestimasi nilai variabel dependen dengan menggunakan lebih dari satu variabel independen.Pengolahan data dikerjakan dengan bantuan program SPSS versi 13.0 for windows (Statistica Program and Service Solution).

Teknik analisis yang digunakan dalam penelitian ini adalah analisis regresi linier berganda menggunakan bantuan program SPSS. Teknik analisis ini digunakan untuk mengetahui kebenaran adanya pengaruh variabel independen dan 
dependen. Dimana dalam hal ini variabel independen adalah Spread Tingkat Suku Bunga (X1), NPL (X2), BOPO (X3) terhadap Profitabilitas (Y) pada BPR Kota Denpasar periode 2014-2016. Regresi linier berganda dapat dirumuskan sebagai berikut, (Nata Wirawan, 2014:254):

$$
\mathrm{Y}=\mathrm{b}_{0}+\mathrm{b}_{1} \mathrm{X}_{1}+\mathrm{b}_{2} \mathrm{X}_{2}+\mathrm{b}_{3} \mathrm{X}_{3}+\mathrm{e}
$$

Keterangan :

$$
\begin{array}{ll}
\mathrm{Y} & =\text { Variabel Profitabilitas BPR } \\
\mathrm{b}_{0} & =\text { Konstanta } \\
\mathrm{b}_{1}, \mathrm{~b}_{2}, \mathrm{~b}_{3} & =\text { Koefisien Regresi }\left(\mathrm{X}_{1}, \mathrm{X}_{2}, \mathrm{X}_{3}\right) \\
\mathrm{X}_{1} & =\text { Spread Tingkat Suku Bunga } \\
\mathrm{X}_{2} & =\text { Non Performing Loan (NPL) } \\
\mathrm{X}_{3} & =\text { BOPO } \\
\mathrm{e} & =\text { error }
\end{array}
$$

\section{HASIL PENELITIAN DAN PEMBAHASAN}

Pengujian deskriptif dilakukan dengan tujuan untuk mengetahui gambaran umum mengenai sampel penelitian. Statistik deskriptif memberikan gambaran tentang jumlah sampel pada penelitian, nilai minimum, nilai maksimum, nilai rata-rata (mean), dan standar deviasi dari masing-masing variabel. Standar deviasi digunakan untuk mengukur seberapa besar atau seberapa tinggi penyimpangan data nilai rata-rata nya.

Tabel 1.

Statistik Deskriptif Variabel Penelitian

\begin{tabular}{lrrrrr}
\hline & N & Minimum & Maximum & Mean & Std.Deviation \\
\hline ROA & 57 & -15.82 & 8.52 & 3.1205 & 3.06731 \\
SPREAD & 57 & 16 & 20.08 & 18.6253 & 1.237 \\
NPL & 57 & 18 & 78.57 & 7.8921 & 10.61448 \\
BOPO & 57 & 57.27 & 163.45 & 10.61448 & 14.23186 \\
Valid N & & & & & \\
(listwise) & 57 & - & - & - & \\
Sumber: Data diolah, 2018 & & & &
\end{tabular}


Ida I DewaAyu Ekadini Badung, Pengaruh Spread....

Berdasarkan Tabel 1 diketahui bahwa terdapat empat variabel penelitian yaitu, ROA, Spread Tingkat Suku Bunga, NPL, BOPO. Jumlah data pengamatan keseluruhan juga dapat dilihat pada tabel yaitu sebanyak 19 sampel. Penjelasan mengenai hasil perhitungan statistik diuraikan sebagai berikut:

Berdasarkan hasil pengujian statistik deskriptif diperoleh nilai ROA minimum dari BPR di Kota Denpasar sebesar -15,82 nilai tersebut dimiliki oleh PT. Hardys Mitra Indonesia, sedangkan nilai maksimum ROA adalah sebesar 8,52 dimiliki oleh PT. BPR Pande Artha Dewata. Nilai rata-rata ROA adalah sebesar 3,1205. Hal ini menunjukkan bahwa setiap tahunnya selama periode 2014-2016 rata-rata ROA mengalami peningkatan karena ROA menunjukkan nilai yang positif. Standar deviasi ROA adalah sebesar 3,06731 atau 306,731 persen artinya terjadi penyimpangan nilai ROA terhadap nilai rata-rata ROA sebesar 3,06731 atau 306,731 persen.

Berdasarkan hasil pengujian statistik deskriptif diperoleh nilai Spread Tingkat Suku Bunga minimum adalah sebesar 16,00. Nilai minimum Spread Tingkat Suku Bunga dimiliki oleh PT. BPR Legian, sedangkan nilai maksimum Spread Tingkat Suku Bunga sebesar 20,08 dimiliki oleh PT. BPR Bali Dananiaga. Nilai rata-rata Spread Tingkat Suku Bunga sebesar 18,6253. Standar deviasi dari Spread Tingkat Suku Bunga adalah sebesar 1,23700 atau 123,700 persen. Hal ini berarti telah terjadi penyimpangan nilai Spread Tingkat Suku Bunga sebesar 1,23700 terhadap nilai rata-rata Spread Tingkat Suku Bunga sebesar sebesar 1,23700 atau 123,700 persen. 
Berdasarkan hasil pengujian statistik deskriptif diperoleh nilai NPL minimum adalah sebesar 0,18. Nilai minimum NPL dimiliki oleh PT. BPR Pusaka sedangkan nilai maksimum NPL sebesar 78,57 dimiliki oleh PT. BPR Hardys Mitra Indonesia. Nilai rata-rata NPL sebesar 7,8921. Standar deviasi dari NPL adalah sebesar 10,61448 atau 1061,448 persen. Hal ini berarti telah terjadi penyimpangan nilai NPL terhadap nilai rata-rata NPL sebesar 10,61448 atau 1061,448 persen.

Berdasarkan hasil pengujian statistik deskriptif diperoleh nilai BOPO minimum adalah sebesar 57,27. Nilai minimum BOPO dimiliki oleh PT. BPR Pande Artha Dewata, sedangkan nilai maksimum BOPO sebesar 163,45 dimiliki oleh PT. BPR Hardys Mitra Indonesia. Nilai rata-rata BOPO sebesar 10,61448. Standar deviasi dari NPL adalah sebesar 14,23186 atau 1423,186 persen. Hal ini berarti telah terjadi penyimpangan nilai BOPO terhadap nilai rata-rata BOPO sebesar 14,23186 atau 1423,186 persen.

Analisis regresi linier berganda digunakan untuk memecahkan rumusan masalah yang ada, yaitu untuk melihat pengaruh antara dua variabel atau lebih. Hasil SPSS dari analisis regresi linier berganda dapat dilihat pada Tabel 2.

Tabel 2.

Hasil Analisis Regresi Linier Berganda

\begin{tabular}{|c|c|c|c|c|c|}
\hline Model & & & Beta & $\mathbf{T}$ & Sig. \\
\hline \multirow[t]{4}{*}{1} & (Constant) & 17.942 & & 9.401 & 0 \\
\hline & Spread & 0.044 & 0.018 & 0.545 & 0.588 \\
\hline & NPL & -0.040 & -0.140 & -3.229 & 0.002 \\
\hline & BOPO & -0.185 & -0.861 & -18.626 & 0 \\
\hline
\end{tabular}

a. Dependen Variabel : ROA

Sumber: Data dioleh, 2018 
Berdasarkan tabel 2 dapat dirumuskan persamaan regresi linier berganda sebagai berikut:

$$
\mathrm{Y}=0,018\left(\mathrm{X}_{1}\right)-0,140\left(\mathrm{X}_{2}\right)-0,861\left(\mathrm{X}_{3}\right)
$$

Keterangan :

$\begin{array}{ll}\mathrm{Y} & =\text { Return On Asset } \\ \mathrm{X}_{1} & =\text { Spread Tingkat Suku Bunga } \\ \mathrm{X}_{2} & =\text { Non Performing Loan } \\ \mathrm{X}_{3} & =\text { Biaya Operasioal Terhadap Pendapatn Operasional }\end{array}$

Persamaan regresi linier berganda tersebut menunjukkan arah masing masing variabel bebas terhadap variabelnya. Persamaan regresi tersebut dapat diuraikan sebagai berikut:

Nilai koefisien regresi variabel Spread sebesar 0,018 artinya bahwa setiap variabel Spread meningkat 1 persen maka ROA akan mengalami peningkatan sebesar 0,018 persen dengan asumsi variabel lain konstan.

Nilai koefisien regresi variabel NPLsebesar -0,140 artinya bahwa setiap variabel NPL meningkat sebesar 1 persen maka ROA akan mengalami penurunan sebesar 0,140 persen dengan asumsi variabel lain konstan.

Nilai koefisien regresi variabel BOPO-0,861 artinya bahwa setiap variabel BOPO meningkat 1 persen makaROAakan mengalami peningkatan sebesar0,861 persen dengan asumsi variabel lain konstan.

Uji kelayakan model dilakukan dengan Uji F. Uji F dilakukan untuk mengetahui apakah semua variabel bebas yaitu Spread, NPL, dan BOPO layak uji. Apabila hasil dari uji Fmenyatakan signifikan $\mathrm{F}$ value $\leq 0,05$ maka 
hubungan antara variabel - variabel bebas signifikan terhadap return on assets dan model regresi yang digunakan dianggap layak uji.

\section{Tabel 3.}

Hasil Uji Kelayakan Model ANOVA $^{b}$

\begin{tabular}{|c|c|c|c|c|}
\hline \multicolumn{2}{|l|}{ Model } & Sum Of & $\mathbf{F}$ & Sig. \\
\hline 1 & Regression & 503.79 & 385.649 & $.000^{\mathrm{a}}$ \\
\hline & Residual & 23.079 & & \\
\hline & Total & 526.868 & & \\
\hline
\end{tabular}

a. Predictors : (Constant), Spread, NPL, BOPO

b. Dependent Variabel : ROA

Sumber: Data diolah, 2018

Berdasarkan Tabel 3. dapat dilihat hasil uji F menunjukkan bahwa nilai $\mathrm{F}$ hitung 385.649 dengan signifikansi sebesar 0,000 yang lebih kecil dari $\alpha=$ 0,05 , ini berarti model yang digunakan dalam penelitian ini layak untuk digunakan.

Uji regresi parsial dilakukan untuk mengetahui signifikan atau tidaknya pengaruh masing - masing variabel bebas terhadap Return On Assets pada BPR di Kota Denpasar periode 2014 - 2016. Signifikansi hasil olahan SPSS dibandingkan dengan signifikansi $(\alpha=0,05)$.

Berdasarkan Tabel 3 dapat dilihat bahwa besar niai koefisien regresi Spread adalah 0,018 dengan taraf signifikansi sebesar 0,588. Hasil signifikansi tersebut menunjukkan bahwa taraf signifikansi Spread lebih besar dari taraf $\alpha=$ 0,05. Ini berarti hipotesis pertama yang menyebutkan Spread berpengaruh positif dan tidak signifikan terhadap Return On Asset diterima. Jadi ini menunjukkan jika Spread meningkat, maka Return On Asset yang dicapai oleh 
BPR di Kota Denpasar akan meningkat juga. Apabila Spread Tingkat Suku Bunga mengalami peningkatan artinya semakin besar suku bunga simpanan maka semakin banyak masyarakat yang tertarik untuk menabung di bank, dan dilain pihak bunga tersebut juga dapat menjadi pendapatan bank yang diterima dari debitur karena kredit yang diberikannya. Berarti laba perusahaan juga mengalami peningkatan, sehingga Spread memiliki hubungan positif namun tidak signifikan terhadap $R O A$ yang artinya tidak signifikan tersebut disebabkan karena tingginya suku bunga pinjaman maupun suku bunga simpanan tetap akan menghasilkan spred margin (selisih) dari kedua bunga tersebut, sehingga suku bunga tidak bisa digunakan untuk mempredeksi ROA, (Fathoni,2017). Hasil penelitian ini mendukung dengan hasil penelitian sebelumnya yang dilakukan oleh Aditya (2016), Wibowo (2013) dan Ashar (2015) yang mendapatkan hasil bahwa Spread bank berpengaruh positif dan tidak signifikan terhadap ROA bank.

Berdasarkan Tabel 3 diketahui nilai koefisien regresi Non Performing Loan sebesar -0,140 dengan taraf signifikansi 0,002. Hasil signifikansi tersebut menunjukkan bahwa taraf signifikansi lebih kecil dari $\alpha=0,05$. Ini berarti hipotesis kedua yang menyebutkan Non Performing Loan berpengaruh negatif dan signifikan terhadap Return On Asset diterima. Jadi ini menunjukkan jika Non Performing Loan yang dicapai oleh BPR di Kota Denpasar akan menurun. NPL mencerinkan risiko kredit, apabila semakin tinggi NPL menandakan semakin buruknya kualitas kredit bank, besarnya resiko kredit bermasalah akan menyebabkan bank harus membentuk cadangan pembentukan (PPAP), pembentukan cadangan penghapusan kredit ini akan 
berdampak pada penurunan laba bank. Hasil penelitian ini didukung oleh hasil penelitian sebelumnya yang dilakukan oleh Devy M (2015), Kolapo et al. (2012), Ngandlan dan Riadi (2010), Han dan JI-yong (2012), dan Joseph et al. (2012) bahwa NPL berpengaruh negatif dan signifikan terhadap ROA bank.

Berdasarkan Tabel 3 dapat dilihat nilai koefisien regresi BOPO sebesar 0,861 dengan taraf signifikansi sebesar 0,000. Hasilsignifikansi tersebut menunjukkan bahwa taraf signifikansi BOPO lebih kecil dari $\alpha 0,05$. Ini berarti hipotesis ketiga yang menyebutkanBOPO berpengaruh negatif dan signifikan terhadap Return On Asset diterima. Jadi ini menunjukkan jika BOPO yang dicapai oleh BPR di Kota Denpasar akan menurun. Jadi hasil penelitian ini mendukung hipotesis yang kedua yaitu BOPO berpengaruh negatif dan signifikan terhadap ROA pada BPR di Kota Denpasar periode 2014-2016. BOPO mencerinkan risiko operasional, apabila semakin tinggi BOPO menandakan semakin buruknya kualitas manajemen bank tersebut dalam mengelola atau memanfaatkan sumber dan sistem yang ada, ini akan berdampak pada penurunan laba bank.Hasil penelitian ini didukung oleh hasil penelitian sebelumnya yang dilakukan oleh Syafri (2012), Defri (2012), dan Nusantara (2009) bahwa BOPO berpengaruh negatif dan signifikan terhadap ROA bank.

Koefisien determinasi berfungsi untuk melihat sejauh mana seluruh variabel independen dapat menjelaskan variabel dependen. Apabila angka koefisien determinasi mendekati 1, maka variabel independen terhadap variabel dependen adalah semakin kuat, yang berarti bahwa variabel-variabel 
independen memberikan hampir semua informasi yang dibutuhkan untuk memprediksi variasi variabel dependen.

Tabel 5.

Hasil Uji Koefisien Determinasi

\begin{tabular}{|c|c|c|c|c|}
\hline Model & $\mathbf{R}$ & $\begin{array}{c}\mathbf{R} \\
\text { Square }\end{array}$ & $\begin{array}{c}\text { Adjusted R } \\
\text { Square } \\
\end{array}$ & $\begin{array}{c}\begin{array}{c}\text { Std. Error Of } \\
\text { The }\end{array} \\
\text { Estimate } \\
\end{array}$ \\
\hline 1 & $.978^{\mathrm{a}}$ & 0.956 & 0.954 & 0.65988 \\
\hline
\end{tabular}

Sumber: Data diolah, 2018

Berdasarkan Tabel 5 dapat dilihat nilai dari $R$ Square adalah 0,956 atau 95,6\% artinya besarnya kemampuan variasi Spread, NPL, dan BOPO dapat menjelaskan variabel ROA sebesar 95,6\% sedangkan sisanya 4,4\% dijelaskan oleh faktor lain yang tidak termasuk dalam model.

Implikasi yang dapat diinterpretasikan dalam penelitian ini adalah spread Tingkat Suku Bunga berpengaruh positif dan tidak signifikan terhadap Return On Asset (ROA). Artinya semakin tinggi rasio Spread maka akanmeningkatkan $R O A$ perusahaan perbankan.

Non performing loan (NPL) berpengaruh negatif dan signifikan terhadap Return On Asset (ROA). Artinya semakin tinggi rasio NPL, maka ROA perusahaan perbankan akan mengalami penurunan, sehingga untuk meningkatkan ROAperusahaan perbankan harus menekan NPL.

BOPO berpengaruh negatif dan signifikan terhadap Return On Asset (ROA). Artinya semakin tinggi rasio BOPO, maka ROA perusahaan perbankan akan mengalami penurunan, sehingga untuk meingkatkan ROA perusahaan perbankan harus memanfaatkan sumber dan sietem yang ada. 


\section{SIMPULAN DAN SARAN}

Berdasarkan pengujian hipotesis yang telah dilakukan menurut teknik analisis berupa regresi linier berganda, maka dapat disimpulkan bahwa spread berpengaruh positif tidak signifikan terhadap Return On Asset (ROA) pada BPR di Kota Denpasar 2014-2016. Nilai tersebut menunjukkan tinginya Suku Bunga Pinjaman maupun Simpanan, tetap menghasilkan spread margin (selisih) kedua bunga tersebut, sehingga suku bunga tidak mempengaruhi profitabilitas BPR Kota Denpasar.

Non Performing Loan (NPL) berpengaruh negatif signifikan terhadap Return On Asset (ROA) Pada BPR di Kota Denpasar 2014-2016. Hasil tersebut menunjukan, semakin tinggi rasio NPL, maka ROA perusahaan perbankan akan mengalami penurunan, begitu sebaliknya. Sehingga untuk meningkatkan ROAperusahaan perbankan harus menekan NPL.

\section{Biaya Operasional Terhadap Pendapatan Operasional (BOPO)} berpengaruh negatif signifikan terhadap Return On Asset (ROA) Pada BPR di Kota Denpasar 2014-2016. Hasil tersebut menunjukan, semakin tinggi rasio BOPO, maka ROA perusahaan perbankan akan mengalami penurunan, sehingga untuk meingkatkan ROA perusahaan perbankan harus memanfaatkan sumber dan sietem yang ada.

Berdasarkan atas simpulan dan hasil analisis, dapat dikemukakan beberapa saran yaitu BPR di Kota Denpasar dalam usaha mencapai Return On Asset (ROA) yang optimal perlu memperhatikan variabel-variabel Spread Tingkat Suku Bunga, Non Performing Loan (NPL), Biaya Operasional terhadap Pendapatan Operasional (BOPO) karena secara simultan mempunyai 
pengaruh yang signifikan terhadap rasio Profitabilitas yang diukur dengan ROA. BPR hendaknya lebih memperhatikan rasio-rasio yang memiliki pengaruh negatif terhadap ROA, apabila komponen tersebut dapat dikelola dengan baik maka dapat mengoptimalkan keuntungan perusahaan.

Bagi peneliti selanjutnya disarankan agar tidak hanya memakai variabel Spread Tingkat Suku Bunga, NPL, dan BOPO untuk menganalisis pengaruhnya terhadap ROA bank. Hal ini dikarenakan masih ada faftor-faktor lain yang dapat mempengaruhi rasio ROA suatu bank. Variabel bebas yang digunakan pada penelitian ini berpengaruh 95,6 persen terhadap ROA dan sisanya 4,4 persen dipengaruhi oleh faktor lainnya. Selain itu, peneliti selanjutnya disarankan untuk menambah tahun pengamatan sehingga hasil yang diperoleh dapat dijadikan dasar pengambilan keputusan bagi pihak-pihak yang membutuhkan.

\section{REFERENSI}

Agus Harjito, Martono. 2008. Manajemen Keuangan. Edisi1.yogyakarta: EKONISIA.

Ashar, Riesty Calona \& Sapari. 2015. Pengaruh Suku Bunga, Rasio Perbankan, dan Aktiva Produktif Terhadap Kinerja Keuangan BPR. Jurnal Ilmu \& Riset Akuntansi, 4 (1), 54-63.

Buchory Acmad Herry. 2015. Banking Intermediation, Operational Efficiency And Risk In The Banking Profitability. International Journal of Business, Economics an Law, 7 (2), 57-63.

Defri. 2012. Pengaruh Capital Adequacy Ratio (CAR), Likuiditas dan Efisiensi Operasional Terhadap Profitabilitas Perusahaan Perbankan yang Terdaftar di BEI. Journal Manajemen, 1 (1), 1-18.

Fahmi, Irfan.2016.Pengantar Manajemen Sumber Daya Manusia Konsep dan Kinerja.Jakarta:Mitra Wacana Media

Hanafi, Mamduh M, 2013, Manajemen Keuangan, Edisi 1, Yogyakarta: BPFE. 
Han, Xiaoxiao, Ji-Yong Seo. 2012. Influential factors in lending and profitability in commercial Chinese banks. African Journal of Business Management. Academic Journals, 6 (36), 10041-10049.

Haneef, Shabaz, dkk. 2012. Impact of Risk Management on Non-Performing Loans and Profitability of Banking Sector Of Pakistan. Journal of Business and Social Science, 3 (7), 307-315.

Haryanto, Sugeng, 2016. Profitability Identification of National Banking Through Credit, Capital, Capital Structure, Efficiency, and Risk Level. Jurnal Diamika Manajemen, 7 (1), 11-21.

Idroes, Ferry N. 2011. Manajemen Risiko Perbankan. Jakarta: PT RajaGrafindo Persada.

Joseph, Mabvure Tendai, 2012. Non Performing Loans in Commercial Banks: A case of CBZ Bank Limited In Zimbabwe. Interdisciplinary Journal of Conteporary Research in Business, 4 (7), 467- 488.

Kalengkongan, Glenda. 2013. Tingkat Suku Bunga dan Inflasi Pengaruhnya terhadap Return On Asset (ROA) pada Industri Perbankan yang Go Public di Bursa Efek Indonesia, Jurnal EMBA, 1 (4), 737-747.

Kasmir, 2014. Bank dan Lembaga Keuangan Lainnya. Edisi Revisi, Cetakan keempatbelas, PT. RajaGrafindo Persada, Jakarta.

Kuncoro, Mudrajad \& Suhardjono, 2011, Manajemen Perbankan, BPFE, Yogyakarta.

Kurnia, Indra, wisnu Mawardi. 2012. Analisis Pengaruh BOPO, EAR, LAR, dan Frim Size Terhadap Kinerja Keuangan. Diponogoro Journal of Management, 2 (3), 49-57.

Kolapo, T. Funso, R., Kolade Ayeni, M. Ojo Oke. 2012. Credit risk and commercial bank performance in Nigeria: A panel model approach. Australian Journal of Busines and Management Research, 2 (2), 31-38.

Mohammad Abdelkarim ALMUMANI. 2013. Impact of Managerial Factors on Commercial Bank Profitability: Empirical Evidence from Jordan. International Journal of Academic Research in Accounting, Finance and Management Sciences, 3 (3), 298-310.

Ndoka Sokol and Islami Manjola. 2016. The Effect Of Credit Risk Management in the Profitability of Albanian Commercial Banks During The Period 2005-2015. European Journal of Sustainbel Development, 5 (3), 445-452.

Ngadlan dan R.M. Riadi. 2010. Pengaruh Camel Terhadap Size Pada Bank yang Listing Pada Bursa Efek Indonesia. Pekbis Jurnal, 2 (3), 382-390. 
Otoritas Jasa Keuangan. 2017. Laporan Data Keuangan Tahun 2014-2016. www.ojk.go.id (diunduh pada tanggal 25 Desember 2017).

Puspita Sari Diana. 2009. Analisis Pengaruh Car, Npl, Pdn, Nim,Bopo, Ldr, Dan Suku Bunga Sbi Terhadap Roa (Studi Pada Bank Devisa di Indonesia Perioda 2003-2007), Jurnal Manajemen UNDIP, 4 (2), 232-241.

Raj Bhattarai Dr. Yuga. 2016. Effect of Non-Performing Loan on the Profitability of Commercial Banks in Nepal. The International Journal Of Business \& Management, 4 (6), 435-442.

Riyadi, Slamet. 2006. Banking Assets and Liability Management. Edisi Ketiga. Jakarta: Lemabaga Penerbitan Fakultas Ekonomi Universitas Indonesia.

Sahara, Ayu Yanita . 2013. Analisis Pengaruh Inflasi, Suku Bunga BI, dan Produk Domestik Bruto Terhadap Return on Asset Bank Syariah di Indonesia. Jurnal Ilmu Manajemen, 1 (1), 149-157.

Siamat, Dahlan, 2005. Manajemen Lembaga Keuangan. Kebijakan Moneter dan Perbankan, Jakarta : Fakultas Ekonomi Universitas Indonesia, edisi kesatu..

Suryanto, 2017. Determinants of Profitability in Commercial Banks of Indonesia an Empirical Study. International Journal of Bussiness and Management Review, 5 (1), 1-11.

Syafri, 2012.Factors affecting bank profitability in Indonesia. The 2012 International Conference Business and Management, 6 (7), 236-242.

Veithzal Rivai, 2013, Manajemen Sumber Daya Manusia Untuk Perusahaan Dari Teori Ke Praktek, Rajagrafindo persada, Bandung.

Wiagustini, Luh Putu. 2014. Dasar-dasar Manajemen Keuangan. Denpasar: Udayana University Press.

Wibowo, Edhi Satriyo. 2013. Analisis Pengaruh Suku Bunga, Inflasi, CAR, BOPO, NPF terhadap Profitabilitas Bank Syariah. Jurnal Manajemen UNDIP, 2 (2), 1-10. 